ISI Impact Factor

(2019-20): 1.628

IC Value (2019): 90.81

$\operatorname{SJIF}(2020)=7.893$

(c) (i) (8)

Copyright@IJCRR

\section{$\bullet \cdot$ \\ IJCRR \\ Section: Healthcare \\ Comparison of Quality of Life, Physical and Respiratory Parameters in Players and Non Players with Spinal Cord Injury}

\author{
Aditi Shah¹, Monalisa Pattnaik², Patitapaban Mohanty ${ }^{3}$
}

'MPT, Swami Vivekananda National lnstitute of Rehabilitation Training and Research, Cuttack, Odisha, lndia; ${ }^{2}$ MPT, Assistant Professor (PT), Swami Vivekanand National Institute of Rehabilitation Training and Research, Cuttack, Odisha, India; ${ }^{3} \mathrm{PhD}$, Assocoate Professor (PT), Swami

Vivekananda National Institute of Rehabilitation Training and Research, Cuttack, Odisha, India.

\title{
ABSTRACT
}

Introduction: Spinal cord injury is a devastating condition making most of the affected population wheelchair-bound. Moreover, affecting cardio-respiratory functioning and the overall life quality of an individual. Sports has been an evident and widely accepted means to strengthen all body systems.

Materials \& Methods: A comparative cross-sectional study with two groups of sports players and non-players with Spinal cord injury [sample size $(n)=34$, for each group] with a mean age of $28.5 \pm 3.956$ in players groups and $31.24 \pm 5.217$ in non-players group, were selected. Quality of life was measured using the WHOQOL BREF questionnaire (including 4 domains i.e. Physical health, Psychological health, Environmental health and social relationships). Physical health parameters included Resting heart rate, Physiological cost index and Muscular endurance. Respiratory parameters (FEV1\%, FVC\% and MVV \%) were recorded using a computerized spirometer (minister model).

Results: In the independent t-test, the Quality of life domains showed a statistically significant difference in the Physical health domain $(p=0.007)$, Psychological health domain $(p=0.00)$ and Environmental domain $(p=0.021)$ while not in the Social relationships domain $(p=0.889)$. Among respiratory parameters; FEV1\% $(p=0.022)$, FVC \% (0.04) showed statistically significant differences while no significant difference in MVV\% was predicted. Among Physical health parameters, the Physiological cost index $(p=0.00)$, Resting heart rate $(p=0.01)$ and Muscular endurance $(p=0.01)$ showed significant differences.

Conclusion: The present study concluded that the overall Quality of life of sports players with spinal cord injury (paraplegic) is improved. Due to participation in sports and training; muscular endurance improved, the Physiological cost index of wheelchair propulsion and Baseline heart is decreased.

Key Words: Baseline heart rate, Muscular endurance, Physiological cost index, Spinal cord injury, Quality of life, Wheelchair sports

\section{INTRODUCTION}

The term 'spinal cord injury refers to damage to the spinal cord resulting from trauma (e.g. a car crash) or disease or degeneration (e.g. cancer). Symptoms of spinal cord injury depend on the severity of the injury and its location on the spinal cord. Symptoms may include partial or complete loss of sensory function or motor control of arms, legs and/or body depending on the level of injury to the spinal cord. ${ }^{1}$

The consequences of sustaining a spinal cord injury (SCI) can be overwhelming and can impact many areas of one's life. ${ }^{2}$ There is a huge impact of SCI on employment and social participation. ${ }^{2}$ Diminishing the negative impact of impairments, and ultimately increasing the well-being of indi- viduals with an SCI is the goal of clinicians and researchers. Indeed, well-being or quality of life (QoL) has become an important outcome in SCI research. ${ }^{3}$

Physical de-conditioning is a state of diminished strength, stamina, and capacity to perform physical activity. A decline in strength, endurance and functional capacity are major health concerns for the individual living with SCI. Sedentary behaviour and inactivity are major risk factors for the development of cardiovascular disease and metabolic disorders and have been linked to decreased muscular strength, reduced aerobic capacity, and increased disability.,5 Time since injury was found to be associated with decreases in all lung volumes. ${ }^{4}$

\section{Corresponding Author:}

Aditi Shah, Swami Vivekananda National Institute of Rehabilitation Training and Research, Cuttack, Odisha, India. Email: ptaditi@gmail.com

ISSN: $2231-2196$ (Print) ISSN: $0975-5241$ (Online)

Received: 24.05 .2021

Revised: 12.07 .2021

Accepted: 05.08 .2021

Published: 13.12 .2021 
A decline in cardiovascular function has also been observed in SCI and can significantly contribute to de-conditioning and reduced functional capacity following the injury. This dysfunction ultimately leads to an inability to challenge the cardiovascular system to the extent required to achieve health and fitness benefits. ${ }^{6,7,8}$

Evidence indicates that strategies to promote exercise and improve the components of fitness positively affect the overall health of individuals with SCI and can reduce the risk of secondary health complications associated with chronic disability. (ACSM's resource manual for guidelines for exercise testing and prescription). There are five health-related components of physical fitness (body composition, cardiovascular endurance, muscular strength, and muscular endurance, flexibility). The absence of health-related fitness attributes have been more closely associated with increased morbidity and mortality in SCI. ${ }^{9-13}$

Individuals with SCI also often have to cope with altered social roles and psychiatric co-morbidities including reactive depression and anxiety disorders. These issues represent major challenges to living with SCI. ${ }^{14}$

A wheelchair is an efficient means of locomotion with optimal independence for a Patient with paraplegia. Estimation of the energy cost of ambulation provides functional efficiency of the user, locomotor efficiency of the wheelchair and potential benefit of the propulsion system.

Sports has always been established as a source of physical and mental fitness, also fits true for Patients with spinal cord injury (SCI) and has shown a decrease in anxiety and depression among sports participants following SCI. ${ }^{15}$

There are established studies showing the positive impact of sports on the life of SCI patients in terms of quality of life, respiratory functions and cardiac functioning, but none of them compared the physical, physiological and psychological parameters in players and non-players with spinal cord injury. ${ }^{16}$

\section{AIMS AND OBJECTIVES OF THE STUDY}

Aim: To compare the quality of life, physical and respiratory parameters between players and non-players following spinal cord injury patients.

\section{OBJECTIVES}

- To compare the psychological, physical health, environmental and social domains of QOL between players and non-players with SCI

- To compare the Physiological cost index of wheelchair propulsion between players and non-players with SCI

- To compare muscular endurance between players and non-players with SCI

- To compare Resting heart rate between players and non-players with SCI
- To compare \% predicted respiratory parameters(FEV1, FVC, MVV) between players and non-players with SCI

\section{Inclusion Criteria}

- More than 3 months of spinal cord injury at thoracic/ lumbar level, both genders, Able to propel wheelchair 100 meters without rest, at least one month after completion of the initial phase of rehabilitation, Able to follow commands, Sports active group of patients must be involved in any sport for greater than 6 months

\section{Exclusion Criteria}

- Patients with orthostatic hypotension, Pressure sores, Recent fractures and pulmonary infection (less than 3 months), Cognitive problems \& mental retardation, Recent pulmonary infection, Cardiac problems, history of Pulmonary Tuberculosis

\section{Instrumentation}

1. Safety pin and whisp of cotton - To test the neurological level of injury

2. World health organization-quality of life (WHOQOL-BREF): Comprises 26 items, which measure the following broad domains: physical health, psychological health, social relationships, and environment. It is possible to derive four domain scores. The four domain scores denote an individual's perception of quality of life in each particular domain. Domain scores are scaled in a positive direction (i.e. higher scores denote the higher quality of life). ${ }^{17}$

\section{Spirometer}

- Minispir model

- PC based USB spirometer

- FDA approved, ATS standard, ISO 9001-2000 certified, ISO 13485

- Measurement parameters FVC, FEV1, MVV.(\% predicted)

4. Stopwatch

\section{PROCEDURE}

68 Spinal cord injury patients were taken non randomly and were divided into two groups; players $(\mathrm{n}=34)$ and non-players $(n=34)$. Participants were recruited from the department of physiotherapy in SVNIRTAR based on the fulfilment of inclusion criteria and exclusion criteria, through informed consent and assessment Performa. The entire procedure of the measurement was explained to them. They were given verbal instructions for the study.

Quality of life of the participants was measured by WHOQOLBREF scale which included 4 domains viz Physical health domain, Psychological health domain, Social relationships and Environmental domain, which was self-administered by the patients. The scores of all 4 domains were calculated separately. 
Physical parameters include Muscular endurance, Physiological cost index and resting heart rate. Muscular endurance was calculated by counting the no. of push-ups at one time while seated in a wheelchair. Physiological cost index (beats/minute) was calculated by using the formula given by Mac Gregor in 1979i.e. PCI = exercise heart rate - resting heart rate/ speed of wheelchair propulsion. Resting heart rate and exercise heart rate $(100 \mathrm{mts}$ wheelchair run) were taken from the right radial artery in a sitting position before and after the completion of the 100 meters wheelchair run on a level surface. Time taken (in minutes) to complete 100 meters wheelchair run was noted from a stopwatch. Speed of wheelchair propulsion was calculated by dividing $100 \mathrm{mt}$ (distance travelled) by the time taken to travel $100 \mathrm{mts}$ (min).

Respiratory parameters (FVC\%, FEV1\%, MVV\%) were measured by Spirometry testing using the computerized Minispir spirometer. Subjects carried out FVC and MVV tests while seated with their wheelchair without any type of abdominal binding support. All tests were carried out following American thoracic society guidelines for respiratory measurement. ${ }^{18}$ Test report was generated in the system.

\section{DATA ANALYSIS}

- Statistical analysis was performed using SPSS version 23.0

- The individual domain scores in WHOQOL- BREF (physical health, psychological health, social relationships and environmental constraints) between two groups were analysed using an independent t-test using a 0.05 level of significance.

- The \% predicted respiratory parameters(FEV1, FVC, MVV) taken by spirometry were analysed using an independent t-test between two groups using a 0.05 level of significance.

- Physiological cost index, muscular endurance and resting heart rate were analysed using an Independent $\mathrm{t}$-test between two groups using a 0.05 Level of significance.

\section{RESULTS}

\section{Comparison of Quality of Life between Players and Non Players with SCI}

A significant difference on independent $t$ test in three domains of QOL was found viz physical health $[\mathrm{t}(66)=8.057$, $\mathrm{p}=0.007]$ (TABLE 1.1), psychological quality of life $[\mathrm{t}(66)=10.89, \mathrm{p}=0.00]$ (TABLE 1.2) and environmental constrain $[\mathrm{t}(66)=10.21, \mathrm{p}=0.021]$ (TABLE 1.4) Whereas in the domain on social relationships $[\mathrm{t}(66)=7.37, \mathrm{p}=0.889]$ (TABLE 1.3) the difference was not statistically significant.

\section{Comparison of Respiratory Parameters be- tween Players and Non Players with Sci}

Independent $t$ test was done. Statistically significant difference were found in FEV1(\%predicted) $[\mathrm{t}(66)=6.165$ $, \mathrm{p}=0.022]$ ( TABLE 2.2) and FVC $(\%$ predicted $)[\mathrm{t}(66)=6.32$ , $\mathrm{p}=0.04]$ (TABLE 2.1 ) while no statistically significant difference in $\operatorname{MVV}(\%$ predicted $)$ [ $\mathrm{t}(66)=8.76, \mathrm{p}=0.17]$ (TABLE 2.3) was found between both the groups.

\section{Comparison of Physical Parameters between Players and Non-Players with Sci}

Independent $t$ test was done. Statistically significant difference between two groups in Physiological cost index of wheelchair propulsion $[\mathrm{t}(66)=-8.524, \mathrm{p}=0.00]$ (TABLE 3.1), Resting heart rate $[\mathrm{t}(66)=-13.26, \mathrm{p}=0.01]$ (TABLE 3.3) and Muscular endurance $[\mathrm{t}(66)=10.203, \mathrm{p}=0.004]$ (TABLE 3.2) was found.

\section{DISCUSSION}

\section{Quality of Life}

In the present study, results of the independent t-test show significant QOL difference in players in the physical health domain $(p=0.007)$ with a mean difference of 9.17 , which could be possibly explained by the physiology which says that Physical activity and exercise are stressors on the body and stress is the body's response to a stressor, that interferes with normal physiology. The body resists the stress, so when stress becomes chronic, as with regular exercise, the body finds ways to resist it. Stress resistance is accomplished with physiological changes within the systems. These changes are referred to as "physiological adaptations". Training adaptations, including better efficiency, resulting in an increased ability to perform physical activity. In addition, exercise's adaptations strengthen the body's systems making them more resistant to illness and disease, resulting in a lower risk for many diseases and better general overall health. ${ }^{19}$

The subjects in the player group in our study were involved in different types of sports(wheelchair basketball, swimming, wheelchair rugby etc) for more than 6 months of period with variable levels of training, with various physiological adaptations the physical health in terms of ADLs, energy and fatigue, mobility, pain and discomfort, sleep and rest, and work capacity (WHOQOL-BREF questionnaire) must have improved.

T-test results show the statistically significant difference in the psychological health domain $(\mathrm{p}=0.00)$ with a mean difference of 21.05. The possible reason for the improvement in psychological health in players group could be predicted from various theories, one of which tells that exercise increases the level of brain norepinephrine and serotonin and that the release of endogenous opioids from the pituitary glands acts as a mood 
enhancer and anti-depressant. Another hypothesis is the thermogenic theory, which suggests that an increase in body temperature has a tranquillizing effect.

T-test results show the statistically significant difference in environmental constraints $(p=0.021$ ) having a mean difference of 31.44. The possible reason for the improvement in the environmental domain includes questions related to financial resources, freedom, physical safety and security, health and social care, home environment, participation in and opportunities for recreation/leisure activities, the physical environment and transport could be that as found in the interview with the participants, after getting involved in sports they started travelling alone to different places for participation in various events at national and international level made them more confident to live independently in any environment and also received opportunities to earn which even more boosted them to stay engaged in sports and opt it as a career.

While social relationships domain of QOL $(\mathrm{p}=0.889)$ was not found to have a significant difference in the independent $\mathrm{t}$-test. The possible reason for the down score in social relationships could be that there were three questions within this domain about personal relationships, sex life, and support from friends(Q 20-22 in WHOQOL-brief questionnaireAppendix III). Out of which one question regarding sex life has not been answered by most of the subjects and results were made by averaging the answers obtained from the other two. Also, there were fewer questions in this domain as compared to the other, so the chances of variability among groups decreases. The other possible reason could be that in a study it was found that all domains showed good internal consistency in $\mathrm{SCI}$ (Cronbach range .74-.78), except for the social relationships domain. ${ }^{20}$ But overall Social relations are enhanced through the involvement in sports as isolation is decreased, sharing with others with common disability experiences are enhanced, and emotional connections with others increase self-confidence. ${ }^{21}$

Increased capacity in the physical domain allows ease of navigation and satisfaction of the environmental domain. Thus involvement in any form of sports has a significant role in improving physical health perception and overall outlook towards various life aspects in subjects with spinal cord injury and in promoting better socialization and community participation.

RESPIRATORY FUNCTIONS (FEV1, FVC AND MVV) In the present study, in the independent t-test significant difference is found in $\operatorname{FEV} 1(p=0.022)$ and $\operatorname{FVC}(p=0.04)$ between the two groups with a mean difference of 13.52 and11.96 respectively. Although no statistically significant difference in MVV ( $\mathrm{p}=0.17)$ between the two groups but the clinical difference was seen.

The increase in FVC and FEVI (\% predicted) could be possi- ble that as the muscular exercise increases the rate and depth of respiration to improve FVC, the consumption of oxygen and the rate of diffusion. ${ }^{22} \mathrm{~A}$ functional connection of the corticospinal tract fibres, from the motor cortex to the spinal motor circuitry of the respiratory and accessory respiratory muscles, has also been shown. ${ }^{23}$

The increase in FVC and FEV1 post-exercise might be related to the enhanced strength of respiratory muscles following training, reduction in air trapping, improvement in lung compliance, reduced airway resistance, reduced blood lactate concentration and improved lactate uptake by these trained muscles (as fuel for their activity) along with a motivation which enforces the subject to take deep inspiration and fill all air passages after training. ${ }^{22}$

The possible reason for the increase in MVV in sports players with SCI could be that the difference in effect size between the sports player group(1.84) and non-player group(2.60) was found to be 0.76 (Cohen's d) i.e. moderate. The physiology behind the increase in MVV could be the combined and perhaps simultaneous effects of several chemical and neural stimuli that initiate and modulate exercise alveolar ventilation. ${ }^{24}$

\section{PHYSIOLOGICAL COST INDEX}

A significant mean difference of $-1.97(p=0.00)$ has been found in PCI between the player's groups and non-players groups with SCI. In the present study, it is established that a lower PCI is required for players as compared to the player group in moving around for about 100 meters at their own pace.

The possible reason for this could be as people become more skilled at performing an exercise, the energy demands during exercise at a given pace are reduced. In a sense, people become more economical.

A study established that the PCI was the least at the preferred speed of walking and increased when the subjects either walked slower or faster than the preferred speed. ${ }^{25}$

This exercise economy effect of sports could be reciprocated in the regular rehabilitation programs to benefit the patients with SCI to perform their ADLs and locomotion effortlessly and at a lower energy cost.

\section{RESTING HEART RATE}

A statistically significant mean difference of $-9.25(\mathrm{p}=0.01)$ has been found in the independent t-test between the two groups. Regarding the Possible mechanisms of the decreasing Heart Rate by the effect of Sports and Physical Activity by Bahrainy et al.the effect may be due to a decrease in the intrinsic heart rate via mechanisms that have not yet been fully understood. ${ }^{26}$

Endurance training creates an imbalance between sympathetic accelerator and parasympathetic depressor activity to 
favour greater vagal parasympathetic dominance. ${ }^{27}$ the effect occurs primarily from increased parasympathetic activity, with some decrease in sympathetic discharge. Training may also decrease the SA node's intrinsic firing rate. These adaptations account for the bradycardia frequently observed among highly conditioned endurance athletes and sedentary individuals who undertake aerobic training. ${ }^{28}$

In a study by Reimers et al., it was found that all sports types resulted in a decrease in the RHR. The higher the initial RHR, the more the RHR decreased due to exercise. The effect occurs after only a few months-on averages, three months with three training sessions per week. ${ }^{29}$

\section{MUSCULAR ENDURANCE}

In the independent t-test, a statistically significant mean difference of 50.5 ( $p=0.004)$ was found between the player's group and the non-players group with SCI. The possible reason for the increase in muscular endurance in the player's group could be justified by the fact that physical conditions improve when it is sufficiently stimulated. ${ }^{30}$ Also due to adaptive changes in the muscles around the shoulder girdle [anterior deltoid, pectoralis major, supraspinatus, infraspinatus, middle trapezius, triceps] involved in the wheelchair propulsion as a result of prolonged time being spent moving around on wheelchair. ${ }^{31}$

\section{CONCLUSION}

The present study concluded that psychological, physical health, environmental domains of quality of life of sports players with spinal cord injury (paraplegic) are improved. Due to participation in sports and training muscular endurance improved, physiological cost index and baseline heart decreased.

\section{LIMITATION}

The study could not establish the effect of individual sports on the parameters.

\section{ACKNOWLEDGEMENT}

The authors express their sincerest gratitude and warm appreciation to the patients who participated in this study. Authors acknowledge immense help received from the scholars whose articles are cited and included in the manuscript. The authors are grateful to all the authors/ editors/publishers of those articles, journals, and books from where the literature of this article has been reviewed and discussed.

Source of Funding: There was no source of funding.
Conflict of Interest: There is no conflict of interest.

Authors' Contribution:

Conception or design of the work.- Aditi Shah and Mrs. Monalisa Pattnaik

Data collection.- Aditi Shah

Data analysis and interpretation.- Mrs. Monalisa Pattnaik

Drafting the article.- Aditi Shah

Critical revision of the article.-Mrs. Monalisa Pattnaik and Dr. Patitapaban Mohanty

Final approval of the version to be published.- Aditi Shah

\section{REFERENCES}

1. WHO, www.who.int, 19 November 2013, https://www.who.int/ news-room/fact- sheets/detail/spinal-cord-injury

2. McKinley WO, Jackson AB, Cardenas DD, DeVivo MJ, Longterm medical complications after traumatic spinal cord injury: a regional model systems analysis. Arch Phys Med Rehabil. Nov 1999, Volume 80(11), page 1402-10.

3. Simpson L A, Eng J.J., Hsieh J. T.C., and Wolfe D. L. The Health and Life Priorities of Individuals with Spinal Cord Injury: A Systematic Review, J. Neurotrauma, May 20 2012, vol. 29( 8), p 1548-1555.

4. Dunlop D, Song J, Arntson E., Semaik P.et al, Sedentary Time in US Older Adults Associated With Disability in Activities of Daily Living Independent of Physical Activity, JPAH, https:// doi.org/10.1123/jpah.2013-0311. 2015;): 93-101.

5. Kesaniemi Y, Danforth E Jr, Jensen M, Kopelman P, Lefebvre $\mathrm{P}$, Reeder B. Dose-response issues concerning physical activity and health: an evidence-based symposium. Med Sci Sports Exerc. 2001; volume 33(6 Supplement), page S351-8.

6. West C, Wong S, Krassioukov A. Autonomic cardiovascular control in Paralympic athletes with spinal cord injury. Med Sci Sports Exerc. 2014; Volume 46(1), p 60-8.

7. West C, Bellantoni A, Krassioukov A. Cardiovascular function in individuals with incomplete spinal cord injury: a systematic review. Topics Spinal Cord Injury Rehabil. 2013; 19(4): 267-78.

8. Waever L, Fleming J, Mathias C, Krassioukov A. Disordered cardiovascular control after spinal cord injury. Handbook of Clinical Neurology. 2012. Volume 109 (3rd Series). Amsterdam: Elsevier; 213-33.

9. Nash M. Exercise as a health-promoting activity following spinal cord injury. J Neurol Phys Therapy. 2005; 29(2): 87-106.

10. Nash M, Cowan R, Kressler J. Evidence-based and heuristic approaches for customization of care in cardiometabolic syndrome after spinal cord injury. J Spinal Cord Med. 2012; 35(5):278-92.

11. Foulon B, Lemay V, Ainsworth V, Martin Ginis K. Enhancing physical activity guidelines: a needs survey of adults with spinal cord injury and health care professionals. Adapt Phys Activ Q. 2012;29: 329-45.

12. Martin Ginis K, Hicks A, Latimer A, Warburton D, Bourne C, Ditor D, et al. The development of evidence-informed physical activity guidelines for adults with spinal cord injury. Spinal Cord. 2011; 49:1088-96.

13. Devillard X, Rimaud D, Roche F, Calmels P. Effects of training programs for spinal cord injury. Annales de Readaptation et de Medicine Physique. 2007; volume 50, p 4908-80. 
14. Tulsky DS. Overview of the Spinal Cord Injury - Quality of Life (SCI-QOL) measurement system, J. Spinal Cord Med., 2015; 38(3): 257-269,

15. Lim S, Shiue Y, Ho C, Yu S, Kao P, Wang J, Kuo J, Anxiety and Depression in Patients with Traumatic Spinal Cord Injury : A Nationwide Population-Based Cohort Study, PLOS, January 12,$2017 ; 1-14$

16. World Health Organization. Quality of Life (WHOQOL)-BREF, World Heal. Organ., 2004.

17. WHO, www. who.int, December 1996, https://www.who.int/ mental_health/media/en/76.pdf

18. ATS, www.thoracic.org, 2019, https://www.thoracic.org/statements/pulmonary-function.php.

19. Oglesby CA, Henige K, McLaughlin DW., Stillwell B. Foundations of Kinesiology. Edition, Jones and Bartlett Publishers, Inc; 2021.chap 6; Exercise and Sports physiology; 119-139.

20. Jang Y, Hsieh C, Wang Y, Wu Y. A Validity Study of the WHOQOL-BREF Assessment in, Arch Phys Med Rehabil, 2004;85 (11):1890-1895.

21. Goodwin D, Johnston K, Gustafson P, Elliott M, Thurmeier R, Kuttai H. It's okay to be a quad: wheelchair rugby players' sense of community, Adapt. Phys. Act. Q.,2009; 26(2):102-117.

22. Fatima SS, Rehman R, Saifullah, Khan Y. Physical activity and its effect on forced expiratory volume. J Pak Med Assoc. 2013 Mar;63(3):310-2. PMID: 23914626.

23. P. H. Ellaway et al., "Review of physiological motor outcome measures in spinal cord injury using transcranial magnetic stimulation and spinal reflexes," in Journal of Rehabilitation Research and Development. 2007;44(1):69-75.
24. Hickey DD, Lundgren CE, Påsche AJ. Influence of exercise on maximal voluntary ventilation and forced expiratory flow at depth. Undersea Biomed Res. 1983 Sep;10(3):241-54. PMID: 6415883.

25. Plotnik M, Bartsch RP, Zeev A, Giladi N, Hausdorff JM. Effects of walking speed on asymmetry and bilateral coordination of gait. Gait Posture. 2013;38(4):864-869. doi:10.1016/j.gaitpost.2013.04.011

26. S. Bahrainy WC, Levy JM. Busey JH. Exercise training bradycardia is largely explained by reduced intrinsic heart rate. Int $\mathrm{J}$ Cardiol.2016; 222:213-216.

27. McArdle WD, Katch FI, Katch VL. Essentials of Exercise Physiology.4th Edition, Lippincott Williams \& Wilkins; 2010, chapter 11: 343.

28. R. Gordan, J. K. Gwathmey, L. Xie, R. Gordan, J. K. Gwathmey, and L. Xie, World Journal of Cardiology, 2015;7(4):204-214.

29. Reimers A., Knapp G., and Reimers C.D. Effects of Exercise on the Resting Heart Rate: A Systematic Review and Meta-Analysis of Interventional Studies. J Clin Med. 2018;7(12):503.

30. Bofosa T, Miangindula B, Nkiama C., Effectiveness of aerobic exercise and strengthening on the cardiorespiratory endurance of paralympic basketball players. Turkish J. Kinesiol.2019;5(2): $57-62$.

31. Mulroy SJ, Farrokhi S, Newsam CJ, Perry J. Effects of spinal cord injury level on the activity of shoulder muscles during wheelchair propulsion: An electromyographic study," Arch. Phys. Med. Rehabil., 2004; 85(6):925-934.

Table 1.1: Independent t test for physical health domain of WHOQOL BREF

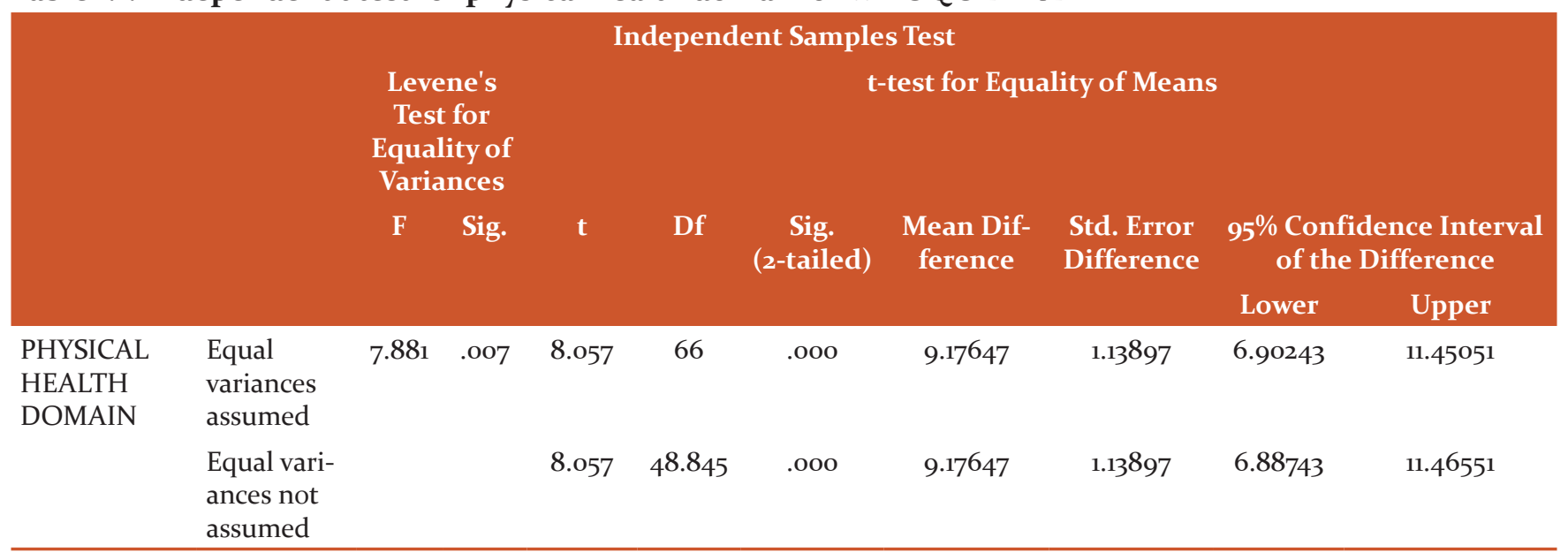


Table 1.2: The Independent t-test for the psychological health domain of WHOQOL BREF

\begin{tabular}{|c|c|c|c|c|c|c|c|c|c|c|}
\hline \multicolumn{11}{|c|}{ Independent Samples Test } \\
\hline & & \multicolumn{2}{|c|}{$\begin{array}{l}\text { Levene's Test } \\
\text { for Equality of } \\
\text { Variances }\end{array}$} & \multicolumn{7}{|c|}{ t-test for Equality of Means } \\
\hline & & \multirow[t]{2}{*}{$\mathbf{F}$} & \multirow[t]{2}{*}{ Sig. } & \multirow[t]{2}{*}{$\mathbf{t}$} & \multirow[t]{2}{*}{ df } & \multirow[t]{2}{*}{$\begin{array}{l}\text { Sig. } \\
\text { (2-tailed) }\end{array}$} & \multirow[t]{2}{*}{$\begin{array}{l}\text { Mean Dif- } \\
\text { ference }\end{array}$} & \multirow[t]{2}{*}{$\begin{array}{l}\text { Std. Error } \\
\text { Differ- } \\
\text { ence }\end{array}$} & \multicolumn{2}{|c|}{$\begin{array}{l}95 \% \text { Confidence } \\
\text { Interval of the } \\
\text { Difference }\end{array}$} \\
\hline & & & & & & & & & Lower & Upper \\
\hline \multirow[t]{2}{*}{$\begin{array}{l}\text { PYSCHOLOGICAL } \\
\text { DOMAIN }\end{array}$} & $\begin{array}{l}\text { Equal } \\
\text { variances } \\
\text { assumed }\end{array}$ & 38.411 & .000 & 10.896 & 66 & .000 & 21.05882 & 1.93268 & 17.20011 & 24.91754 \\
\hline & $\begin{array}{l}\text { Equal } \\
\text { variances } \\
\text { not as- } \\
\text { sumed }\end{array}$ & & & 10.896 & 52.168 & .000 & 21.05882 & 1.93268 & 17.18092 & 24.93673 \\
\hline
\end{tabular}

Table 1.3: Independent $t$ test between two groups for social relationship domain of WHOQOL BREF

Independent Samples Test

\begin{tabular}{|c|c|c|c|c|c|c|c|c|c|c|}
\hline & & \multicolumn{2}{|c|}{$\begin{array}{l}\text { Levene's } \\
\text { Test for } \\
\text { Equality of } \\
\text { Variances }\end{array}$} & \multicolumn{7}{|c|}{ t-test for Equality of Means } \\
\hline & & \multirow[t]{2}{*}{$\mathbf{F}$} & \multirow[t]{2}{*}{ Sig. } & \multirow[t]{2}{*}{$\mathbf{T}$} & \multirow[t]{2}{*}{ Df } & \multirow[t]{2}{*}{$\begin{array}{c}\text { Sig. } \\
\text { (2-tailed) }\end{array}$} & \multirow[t]{2}{*}{$\begin{array}{l}\text { Mean Dif- } \\
\text { ference }\end{array}$} & \multirow[t]{2}{*}{$\begin{array}{l}\text { Std. Error } \\
\text { Difference }\end{array}$} & \multicolumn{2}{|c|}{$\begin{array}{l}95 \% \text { Confidence } \\
\text { Interval of the Dif- } \\
\text { ference }\end{array}$} \\
\hline & & & & & & & & & Lower & Upper \\
\hline \multirow[t]{2}{*}{$\begin{array}{l}\text { SOCIAL } \\
\text { RELATIONS } \\
\text { DOMAIN }\end{array}$} & $\begin{array}{l}\text { Equal } \\
\text { variances } \\
\text { assumed }\end{array}$ & .019 & .889 & $7 \cdot 378$ & 66 & .000 & 18.38235 & 2.49143 & 13.40805 & $23 \cdot 35665$ \\
\hline & $\begin{array}{l}\text { Equal vari- } \\
\text { ances not } \\
\text { assumed }\end{array}$ & & & $7 \cdot 378$ & $65.8 S_{29}$ & .000 & 18.38235 & 2.49143 & 13.40781 & $23 \cdot 35689$ \\
\hline
\end{tabular}

Table 1.4: Independent t-test between two groups for environmental health domain of WHOQOL BREF

\begin{tabular}{|c|c|c|c|c|c|c|c|c|c|c|}
\hline \multicolumn{11}{|c|}{ Independent Samples Test } \\
\hline & & \multicolumn{2}{|c|}{$\begin{array}{l}\text { Levene's } \\
\text { Test for } \\
\text { Equality of } \\
\text { Variances }\end{array}$} & \multicolumn{7}{|c|}{ t-test for Equality of Means } \\
\hline & & \multirow[t]{2}{*}{$\mathbf{F}$} & \multirow[t]{2}{*}{ Sig. } & \multirow[t]{2}{*}{$\mathbf{t}$} & \multirow[t]{2}{*}{ Df } & \multirow[t]{2}{*}{$\begin{array}{c}\text { Sig. } \\
\text { (2-tailed) }\end{array}$} & \multirow[t]{2}{*}{$\begin{array}{l}\text { Mean Dif- } \\
\text { ference }\end{array}$} & \multirow[t]{2}{*}{$\begin{array}{l}\text { Std. Error } \\
\text { Difference }\end{array}$} & \multicolumn{2}{|c|}{$\begin{array}{l}95 \% \text { Confidence } \\
\text { Interval of the Dif- } \\
\text { ference }\end{array}$} \\
\hline & & & & & & & & & Lower & Upper \\
\hline \multirow[t]{2}{*}{$\begin{array}{l}\text { ENVIRONMENT } \\
\text { DOMAIN }\end{array}$} & $\begin{array}{l}\text { Equal } \\
\text { variances } \\
\text { assumed }\end{array}$ & $5 \cdot 550$ & .021 & 10.219 & 66 & .000 & 31.44118 & 3.07675 & 25.29824 & $37 \cdot 58412$ \\
\hline & $\begin{array}{l}\text { Equal } \\
\text { variances not } \\
\text { assumed }\end{array}$ & & & 10.219 & $49 \cdot 928$ & .000 & 31.44118 & 3.07675 & 25.26111 & 37.62124 \\
\hline
\end{tabular}




\section{RESPIRATORY PARAMETERS ANALYSIS}

Table 2.1: Independent t-test for FVC\% predicted

\begin{tabular}{|c|c|c|c|c|c|c|c|c|c|c|}
\hline \multicolumn{11}{|c|}{ Independent Samples Test } \\
\hline & & \multicolumn{2}{|c|}{$\begin{array}{l}\text { Levene's } \\
\text { Test for } \\
\text { Equality of } \\
\text { Variances }\end{array}$} & \multicolumn{7}{|c|}{ t-test for Equality of Means } \\
\hline & & $\mathbf{F}$ & Sig. & $\mathbf{t}$ & df & $\begin{array}{l}\text { Sig. } \\
\text { (2-tailed) }\end{array}$ & $\begin{array}{l}\text { Mean Dif- } \\
\text { ference }\end{array}$ & $\begin{array}{l}\text { Std. Error } \\
\text { Difference }\end{array}$ & $\begin{array}{l}95 \% \text { Cor } \\
\text { Interval } \\
\text { ference }\end{array}$ & $\begin{array}{l}\text { idence } \\
\text { f the Dif- }\end{array}$ \\
\hline & & & & & & & & & Lower & Upper \\
\hline \multirow[t]{2}{*}{$\mathrm{FVC} \%$} & $\begin{array}{l}\text { Equal variances } \\
\text { assumed }\end{array}$ & $4 \cdot 383$ & .040 & 6.320 & 66 & .000 & 11.96147 & 1.89251 & 8.18296 & 15.73999 \\
\hline & $\begin{array}{l}\text { Equal variances } \\
\text { not assumed }\end{array}$ & & & 6.320 & 49.236 & .000 & 11.96147 & 1.89251 & 8.15879 & $15 \cdot 76415$ \\
\hline
\end{tabular}

Table 2.2: Independent t-test for FEV1\% predicted

\begin{tabular}{|c|c|c|c|c|c|c|c|c|c|c|}
\hline \multicolumn{11}{|c|}{ Independent Samples Test } \\
\hline & & \multicolumn{2}{|c|}{$\begin{array}{l}\text { Levene's } \\
\text { Test for } \\
\text { Equality of } \\
\text { Variances }\end{array}$} & \multicolumn{7}{|c|}{ t-test for Equality of Means } \\
\hline & & \multirow[t]{2}{*}{$\mathbf{F}$} & \multirow[t]{2}{*}{ Sig. } & \multirow[t]{2}{*}{$\mathbf{T}$} & \multirow[t]{2}{*}{ df } & \multirow[t]{2}{*}{$\begin{array}{l}\text { Sig. } \\
\text { (2-tailed) }\end{array}$} & \multirow[t]{2}{*}{$\begin{array}{l}\text { Mean Dif- } \\
\text { ference }\end{array}$} & \multirow[t]{2}{*}{$\begin{array}{l}\text { Std. Error } \\
\text { Difference }\end{array}$} & \multicolumn{2}{|c|}{$\begin{array}{c}95 \% \text { Confidence Interval } \\
\text { of the Difference }\end{array}$} \\
\hline & & & & & & & & & Lower & Upper \\
\hline \multirow[t]{2}{*}{ FEV $1 \%$} & $\begin{array}{l}\text { Equal } \\
\text { variances } \\
\text { assumed }\end{array}$ & $5 \cdot 546$ & .022 & 6.165 & 66 & .000 & $13 \cdot 52176$ & 2.19316 & 9.14299 & 17.90054 \\
\hline & $\begin{array}{l}\text { Equal vari- } \\
\text { ances not } \\
\text { assumed }\end{array}$ & & & 6.165 & 47.831 & .000 & $13 \cdot 52176$ & 2.19316 & 9.11172 & $17 \cdot 93180$ \\
\hline
\end{tabular}

Table 2.3: Independent t-test for MVV\% predicted

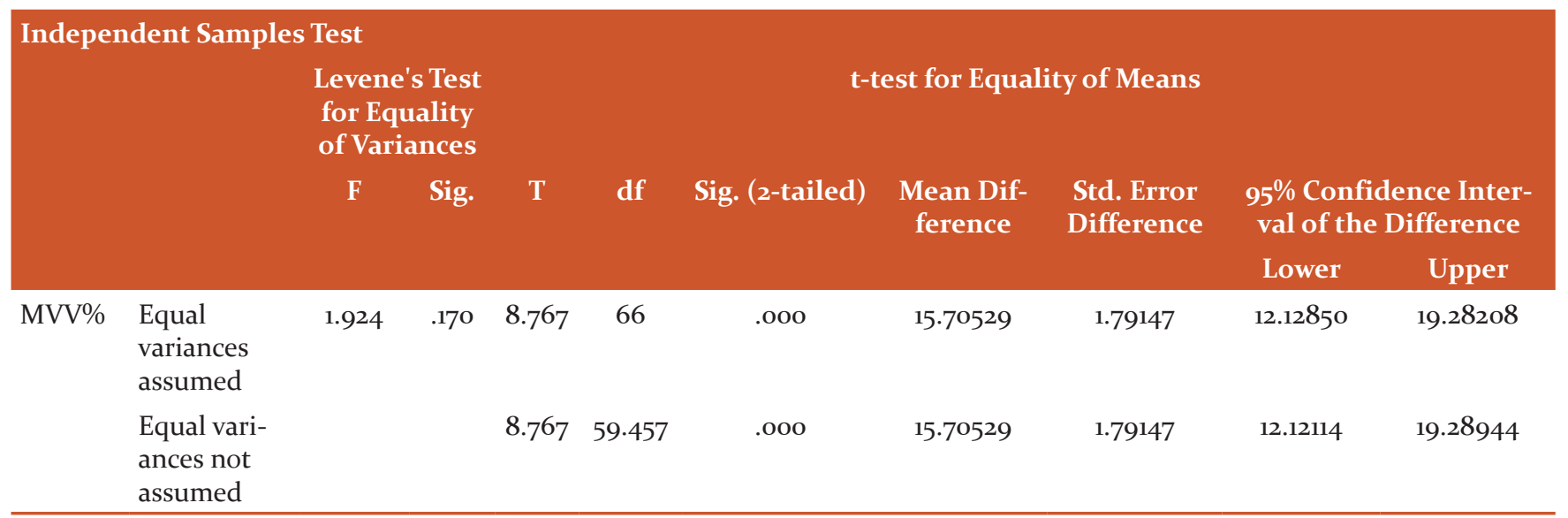




\section{PHYSICAL HEALTH PARAMETERS}

Table 3.1: Independent t-test between two groups for physiological cost index

Independent Samples Test

\begin{tabular}{|c|c|c|c|c|c|c|c|c|c|c|}
\hline & & \multicolumn{2}{|c|}{$\begin{array}{l}\text { Levene's } \\
\text { Test for } \\
\text { Equality of } \\
\text { Variances }\end{array}$} & \multicolumn{7}{|c|}{ t-test for Equality of Means } \\
\hline & & \multirow[t]{2}{*}{$\mathbf{F}$} & \multirow[t]{2}{*}{ Sig. } & \multirow[t]{2}{*}{$\mathbf{T}$} & \multirow[t]{2}{*}{ df } & \multirow[t]{2}{*}{$\begin{array}{c}\text { Sig. } \\
\text { (2-tailed) }\end{array}$} & \multirow{2}{*}{$\begin{array}{l}\text { Mean } \\
\text { Differ- } \\
\text { ence }\end{array}$} & \multirow[t]{2}{*}{$\begin{array}{l}\text { Std. Error } \\
\text { Difference }\end{array}$} & \multicolumn{2}{|c|}{$\begin{array}{l}95 \% \text { Confidence Inter- } \\
\text { val of the Difference }\end{array}$} \\
\hline & & & & & & & & & Lower & Upper \\
\hline \multirow[t]{2}{*}{$\begin{array}{l}\text { PHYSIOLOGICAL } \\
\text { COST INDEX }\end{array}$} & $\begin{array}{l}\text { Equal } \\
\text { variances } \\
\text { assumed }\end{array}$ & 39.187 & .000 & -8.524 & 66 & .000 & -1.79794 & .21093 & -2.21909 & -1.37680 \\
\hline & $\begin{array}{l}\text { Equal vari- } \\
\text { ances not } \\
\text { assumed }\end{array}$ & & & -8.524 & 34.282 & .000 & -1.79794 & .21093 & -2.22648 & -1.36940 \\
\hline
\end{tabular}

Table 3.2: Independent t-test for muscular endurance

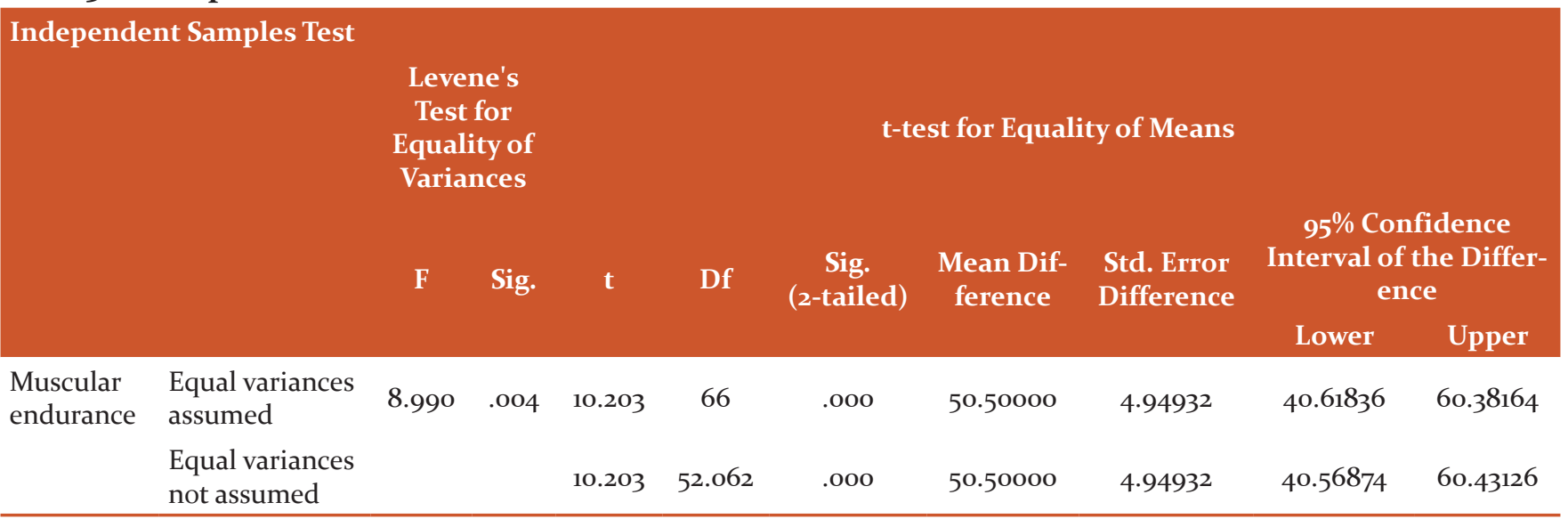

Table 3.3: Independent t-test for resting heart rate

\begin{tabular}{|c|c|c|c|c|c|c|c|c|c|c|}
\hline \multicolumn{11}{|c|}{ Independent Samples Test } \\
\hline & & \multicolumn{2}{|c|}{$\begin{array}{l}\text { Levene's } \\
\text { Test for } \\
\text { Equality of } \\
\text { Variances }\end{array}$} & \multicolumn{7}{|c|}{ t-test for Equality of Means } \\
\hline & & \multirow[t]{2}{*}{$\mathbf{F}$} & \multirow[t]{2}{*}{ Sig. } & \multirow[t]{2}{*}{$\mathbf{t}$} & \multirow[t]{2}{*}{ df } & \multirow[t]{2}{*}{$\begin{array}{c}\text { Sig. } \\
(2 \text {-tailed })\end{array}$} & \multirow[t]{2}{*}{$\begin{array}{l}\text { Mean Dif- } \\
\text { ference }\end{array}$} & \multirow[t]{2}{*}{$\begin{array}{l}\text { Std. Error } \\
\text { Difference }\end{array}$} & \multicolumn{2}{|c|}{$\begin{array}{l}95 \% \text { Confidence Inter- } \\
\text { val of the Difference }\end{array}$} \\
\hline & & & & & & & & & Lower & Upper \\
\hline \multirow[t]{2}{*}{$\begin{array}{l}\text { RESTING } \\
\text { HEART } \\
\text { RATE }\end{array}$} & $\begin{array}{l}\text { Equal } \\
\text { variances } \\
\text { assumed }\end{array}$ & 7.000 & .010 & -13.269 & 66 & .000 & -9.85294 & .74253 & -11.33545 & -8.37043 \\
\hline & $\begin{array}{l}\text { Equal vari- } \\
\text { ances not } \\
\text { assumed }\end{array}$ & & & -13.269 & 59.230 & .000 & -9.85294 & .74253 & -11.33862 & -8.36726 \\
\hline
\end{tabular}

